\title{
On the polar edge: the status of the northern gannet (Morus bassanus) in the Barents Sea in 2015-16
}

\author{
Robert T. Barrett ${ }^{\mathrm{a}}$, Hallvard Strøm ${ }^{\mathrm{b}}$ \& Mikhail Melnikov (D) ${ }^{c}$ \\ aDepartment of Natural Sciences, Tromsø University Museum, Tromsø, Norway; ${ }^{b}$ Norwegian Polar Institute, Fram Centre, Tromsø, \\ Norway; 'Kandalaksha State Nature Reserve, Kandalaksha, Murmanskaya obl., Russia
}

\begin{abstract}
During its population recovery in the North Atlantic in the early 1900s, the northern gannet (Morus bassanus) established its first colony in Norway at Runde in 1946. Since the 1960s, gannets have established (and later abandoned) several small colonies in the north of the country. These colonies have been regularly monitored, and in 2015-16 ca. 3300 apparently occupied nests (AON) were counted in seven colonies in northern Norway. Two colonies that existed in 2008 had been abandoned and four new ones established. Two of the latter were again abandoned before 2015 . In 1995, one pair established a colony at Kharlov on the Kola Peninsula, Russia, where numbers increased to 200-250 AON in 2016. The newest and world's northernmost colony was established at Bjørnøya (Bear Island) in 2011, extending the species' breeding range well into the Arctic. These recent establishments are thought to be associated with a warming of the Barents Sea and the northward spread of common prey of the gannet such as herring and mackerel. This paper documents recent establishments, growths and abandonments of colonies at the gannet's northern limit of distribution.
\end{abstract}

\section{KEYWORDS}

Colony establishment: breeding range; population change; ocean climate

\section{ABBREVIATIONS}

AON: apparently occupied nests; SEAPOP: Seabird Population Management and Petroleum Operations (monitoring and mapping programme for Norwegian seabirds)
Since the early 1900s, the population of the northern gannet (Morus bassanus, hereafter gannet) has been increasing throughout its breeding range on both sides of the North Atlantic at a rate of about 3\% $\mathrm{y}^{-1}$ (Nelson 2002; Newton et al. 2015; Murray, Harris et al. 2015). The gannet first colonized Norway in the south-west of the country (at Runde) in the mid1940s and spread to three colonies in northern Norway in the early 1960s (Brun 1967, 1970). More colonies were later established in the north, and total numbers reached ca. 4700 AON in 2008 (Barrett \& Folkestad 1996; Barrett 2008; Pettex et al. 2015). Of these, ca. $2000 \mathrm{AON}$ were at Runde, and the remaining $2700 \mathrm{AON}$ north of the Arctic Circle. The latter were distributed among seven colonies between the tip of the Lofoten Islands and Syltefjord in the far north-east of the country with the colony on the island of Storstappen, in Gjesvær, then the northernmost in the world (at $71^{\circ} 09^{\prime} \mathrm{N}$; Barrett 2008; Pettex et al. 2015). In 1993, the species spread eastwards with a pair being seen prospecting on Kharlov, an island off the Kola Peninsula, Russia (Fig. 1), and an egg was seen in the first nest three years later (Krasnov \& Barrett 1997). This was followed 15 years later by the establishment of a colony at the south end of Bjørnøya (Bear Island, Fig. 1) at $74^{\circ} 21^{\prime} \mathrm{N}$ in 2011 when two nests/sites were counted on the small, steep-sided island Alkeholmen (Strøm unpubl. data).
Once established, gannet numbers increased steadily in the northernmost colonies in mainland Norway, but with clear regional differences in progression. After reaching a maximum of $1500 \mathrm{AON}$ in Nordland and Troms counties (Fig. 2) in 1991, they declined to 590 in 2005. In the county of Finnmark, however, numbers nearly doubled between 1995 and 2008, mainly due to the expansion of the colony at Storstappen from ca. 500 to 1200-1300 AON (Barrett 2008). During the decline in Lofoten/Vesterålen, in Nordland county, there was also a marked reorganization of the gannets' distribution, with four colonies abandoned and three new ones established (Barrett 2008). Here we present the results of censuses made on the Russian and Bjørnøya colonies since their establishments and on the Norwegian mainland colonies between 2008 and 2016, including descriptions of three new colonies. This summary is presented to coincide with published results of decadal counts made in the UK and Iceland in 2013-15 (Newton et al. 2015; Murray, Harris et al. 2015; Murray, Morgan et al. 2015; Gardarsson in press).

\section{Methods}

Between 2008 and 2016, nearly all gannet colonies in northern Norway were censused at 1-2 year intervals. Counts were made of AON (AON = single or pairs of birds at sites where nest material was observed) on 


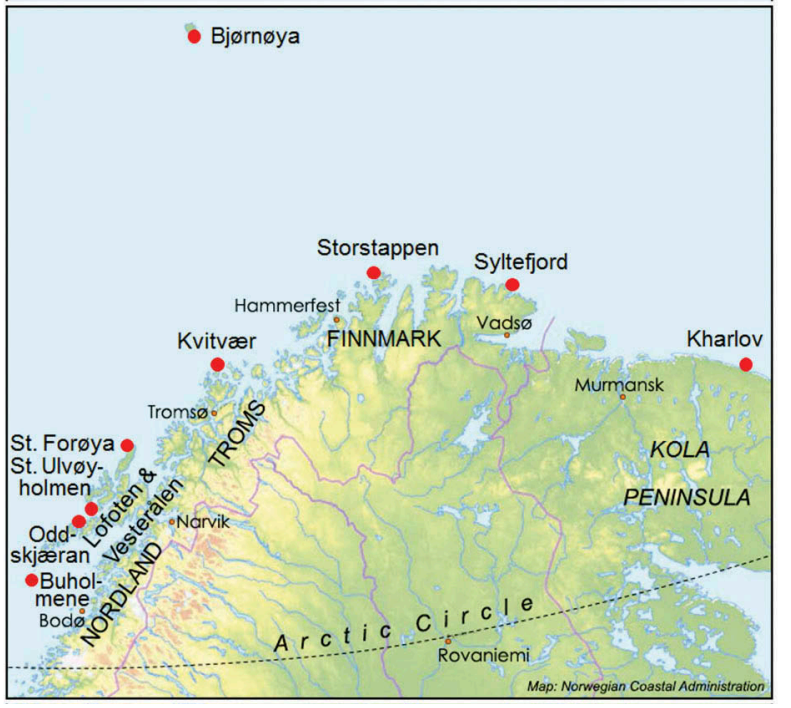

Figure 1. Map of extant northern gannet (Morus bassanus) colonies in northern Norway and the southern Barents Sea in 2015-16 (red dots).

aerial photographs (taken from ca. $150 \mathrm{~m}$, airspeed ca. 100 knots). Occupied sites without nest material were not counted. They may be attended by nonbreeding pairs that often abandon the site when approached by the low-flying aircraft (Murray, Harris et al. 2015; pers. obs.) and would therefore have been missed. The colony at Syltefjord was censused less regularly (bad weather often preventing access) using photographs taken from land. More details of methods are given in Montevecchi et al. (1987) and dates of counts are given in Table 1. Counts were made of digital images on the computer screen using Photoshop. Establishment of new colonies in the region were reported by local fishermen and/or bird watchers and were followed up during the aerial surveys as soon as possible.

At Kharlov, ground counts of occupied nests were carried out annually (except in 2003 and 2012-14) using a combination of direct counts and counts from photographs. This was done during the incubation period with slight corrections made later in the season when chicks were ringed. At Bjørnøya direct counts were made using a telescope at a distance of ca. $280 \mathrm{~m}$ also during incubation in 2011-15. In 2016, direct counts were combined with counts from photographs.

\section{Results}

In 2015-16, there were seven occupied colonies along the mainland of northern Norway, totalling ca. 3300 AON (Table 1, Fig. 1). In Finnmark, the colony at Syltefjord had remained relatively stable since 2008, while that at Storstappen increased by $17 \%$ between 2008 and 2015. In Troms and Nordland, numbers increased from ca. $900 \mathrm{AON}$ in 2008 to ca. 1300
AON in 2015 (Fig. 2). This was despite a drop from 326 AON at Kvitvær-the one colony in Troms-in 2008 to only $21 \mathrm{AON}$ in 2015. During this period, two colonies in Nordland were abandoned and two new ones established. The former, Kvitholmen and Kvalnesflesa, were never larger than 50 and $76 \mathrm{AON}$ and were found abandoned in 2010 and 2015 respectively. Kvitholmen was found occupied for the first time in 2008 and lasted a maximum of two seasons (an estimated $40 \mathrm{AON}$ were counted from the air in a different survey on 5 August 2009 [M. Husdal, County Governor of Nordland, pers. comm.]), whereas the colony at Kvalnesflesa declined steadily from $76 \mathrm{AON}$ in 2008 to 0 in 2015 (Table 1).

In July 2009, >100 gannets were seen circling over and on land at Litle (Little) Forøya near Bleik, Andøya (Figs. 1, 3; F. Broms, pers. comm.) and in August 2009, 'tens' of gannets were seen from land over Oddskjæran, off Gimsøya, Lofoten (Figs. 1 and 4; J. Stenersen, pers. comm.). During the aerial survey in 2010, 75 gannet AON were counted on Litle Forøya, and 20 gannet AON were counted among 370 pairs of great cormorants (Phalacrocorax carbo) on Oddskjæran. The nests on low-lying ( $<5 \mathrm{~m}$ a.s.l.) Litle Forøya, however, were washed away annually during spring storms (E. Olsen, pers. comm.) and despite new nests being built after the events (as seen from the aerial surveys), the colony was abandoned after five years (Table 1). The gannets may have moved to the neighbouring Store (Big) Forøya (ca. $700 \mathrm{~m}$ to the south-east; Fig. 3) where $88 \mathrm{AON}$ were found among $165 \mathrm{AON}$ of great cormorants in 2012, increasing to $187 \mathrm{AON}$ in 2015 (pers. obs.). In the context of this summary, the two Forøya islands are considered as one colony. Photographs of the other northern Norwegian colonies can be seen in Barrett (2008).

After the colonization of Kharlov in 1995, gannet numbers increased slowly at first and then rapidly to 335 AON in 2009 after which they decreased and stabilized around 200-250 AON (Table 2). Like the

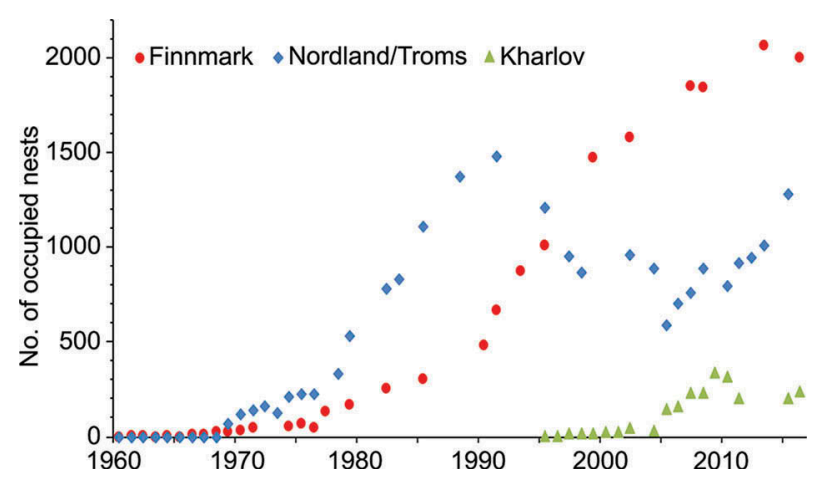

Figure 2. Counts of northern gannet AON in Finnmark, Nordland/Troms and Kharlov since their establishment in the Barents Sea. 
Table 1. Counts of northern gannet AON in northern Norwegian colonies in 2008-2016. All counts are from aerial photographs, with the exception of those at Syltefjord, which was photographed from land. A dash indicates no counts were made.

\begin{tabular}{|c|c|c|c|c|c|c|c|c|c|}
\hline Colony & & & 2008 & 2010 & 2011 & 2012 & 2013 & 2015 & 2016 \\
\hline Dates of surveys & County & Position & $27 \& 29^{a}$ June & 2 June & $2 \& 26^{\text {a June }}$ & 28 June & $10^{\mathrm{b}} \& 14 \mathrm{May}$ & $26 \& 27^{\mathrm{b}}$ May & 16 June \\
\hline Syltefjord & Finnmark & $70^{\circ} 36^{\prime} \mathrm{N}, 30^{\circ} 18^{\prime} \mathrm{E}$ & $600^{c}$ & - & - & - & $561^{d}$ & - & 563 \\
\hline Storstappen & Finnmark & $71^{\circ} 09^{\prime} \mathrm{N}, 25^{\circ} 19^{\prime} \mathrm{E}$ & 1244 & - & 1412 & - & 1500 & 1450 & - \\
\hline Kvitvær & Troms & $70^{\circ} 13^{\prime} \mathrm{N}, 18^{\circ} 42^{\prime} \mathrm{E}$ & 326 & - & 0 & - & 33 & 21 & - \\
\hline Store Forøya & Nordland & $69^{\circ} 18^{\prime} \mathrm{N}, 15^{\circ} 59^{\prime} \mathrm{E}$ & 0 & 0 & 0 & 88 & 119 & 187 & - \\
\hline Litle Forøya & Nordland & $69^{\circ} 18^{\prime} \mathrm{N}, 15^{\circ} 58^{\prime} \mathrm{E}$ & 0 & 75 & 75 & 59 & 17 & 0 & - \\
\hline Skarvklakken & Nordland & $69^{\circ} 09^{\prime} \mathrm{N}, 15^{\circ} 39^{\prime} \mathrm{E}$ & 0 & 0 & 0 & 0 & 0 & 0 & - \\
\hline Kvitholmen & Nordland & $69^{\circ} 09^{\prime} \mathrm{N}, 15^{\circ} 41^{\prime} \mathrm{E}$ & 50 & 0 & 0 & 0 & 0 & 0 & - \\
\hline St. Ulvøyhomen & Nordland & $68^{\circ} 31^{\prime} \mathrm{N}, 14^{\circ} 31^{\prime} \mathrm{E}$ & 308 & 308 & 294 & 254 & 319 & 330 & - \\
\hline Oddskjæran & Nordland & $68^{\circ} 20^{\prime} \mathrm{N}, 14^{\circ} 15^{\prime} \mathrm{E}$ & 0 & 20 & 39 & 55 & 19 & 13 & - \\
\hline Kvalnesflesa & Nordland & $68^{\circ} 21^{\prime} \mathrm{N}, 13^{\circ} 59^{\prime} \mathrm{E}$ & 76 & 33 & 12 & 9 & 2 & 0 & - \\
\hline Buholmene & Nordland & $67^{\circ} 46^{\prime} \mathrm{N}, 12^{\circ} 45^{\prime} \mathrm{E}$ & 126 & 357 & 495 & 479 & 498 & 725 & - \\
\hline
\end{tabular}

${ }^{\mathrm{a}}$ Storstappen. ${ }^{\mathrm{b}}$ Kvitvær and Storstappen. ${ }^{\mathrm{c}} 17$ June. ${ }^{\mathrm{d}} 2$ July.

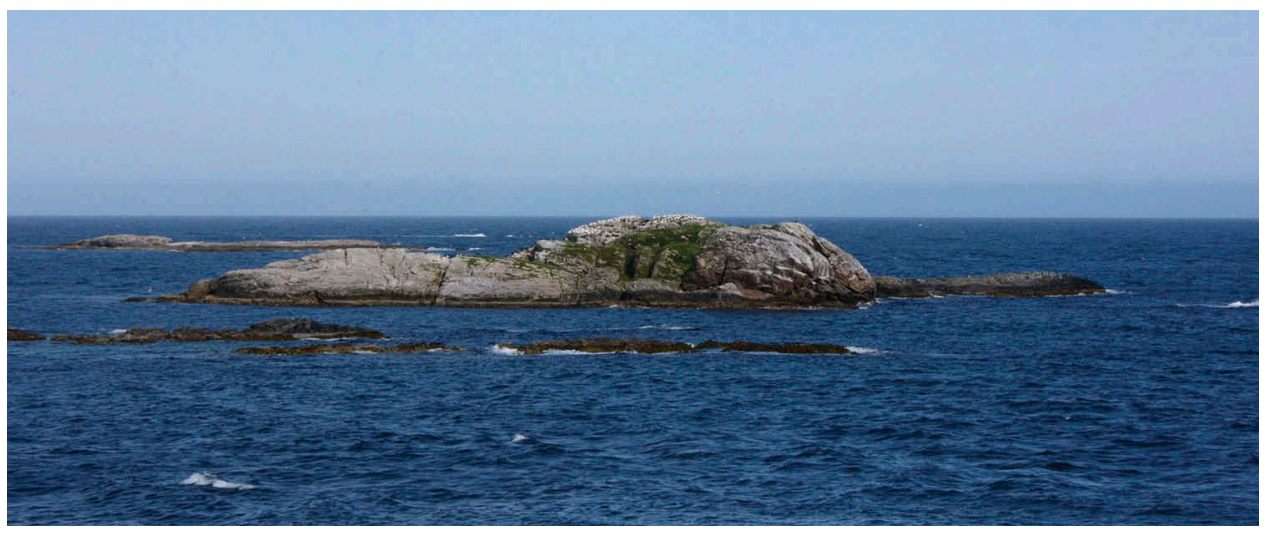

Figure 3. Litle Forøya (low-lying island to the left in the background) and Store Forøya (large island in the middle rising to 16 asl) as photographed from the mainland (distance to Store Forøya = $500 \mathrm{~m}$ ), 17 July 2015.

colony at Syltefjord, the establishment at Kharlov was on and among ledges occupied by common guillemots (Uria aalge) in a colony long occupied by a variety of cliff-nesting seabirds (Fig. 5). The colony subsequently spread to cliffs occupied by black-legged kittiwakes (Rissa tridactyla) and up to the turf-covered plateau at the top of the cliff. The recent fluctuations in numbers have been mainly in this latter part of the colony while numbers have remained more-orless stable on the cliff face.

On Bjørnøya, the population increased from two pairs in 2011 to 10 occupied nests in 2013 and 52 in 2016 (Table 2). As in several of the mainland colonies, the establishment on Bjørnøya took place on rocky outcrops already occupied by common guillemots, and some northern fulmars (Fulmarus glacialis), along the outer rim of the top of the small island (Fig. 6).

\section{Discussion}

The establishment of a colony on Bjørnøya signalled a major $(356 \mathrm{~km})$ northward extension of the gannet's breeding distribution further into the Arctic, enhancing the already well-earned descriptive 'northern' in the species' vernacular name (Nelson 2002). It also increased the latitudinal range of gannets in
Europe, the southernmost being Rouzic, Brittany, $48^{\circ} 53^{\prime} \mathrm{N}$ (Nelson 2002), by $14 \%$ (from $22^{\circ} 15^{\prime}$ to $25^{\circ} 27^{\prime}$ ). (This is ignoring outlying breeding attempts, some of which were successful, in the 1990s in Mediterranean France and in Baia dell'Olivo at Porto Venere, Italy, in 2012-15 [Giagnoni et al. 2015.]) The spread of the gannet to Bjørnøya coincided with an unprecedented inflow of warm Atlantic

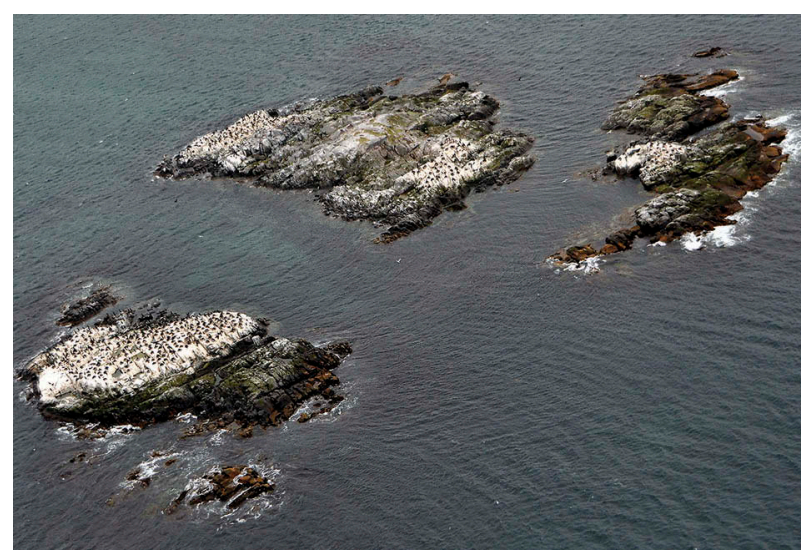

Figure 4. Aerial photograph of great cormorant and northern gannet colony on Oddskjæran, 2 June 2010. Most gannets were nesting on the island below, left. One gannet nest was seen on the island to the right in 2012. 
Table 2. Counts of northern gannet AON on Kharlov, Russia $\left(68^{\circ} 49^{\prime} \mathrm{N}, 37^{\circ} 20^{\prime} \mathrm{E}\right)$, and on Bjørnøya $\left(74^{\circ} 21^{\prime} \mathrm{N}, 19^{\circ} 07^{\prime} \mathrm{E}\right)$.

\begin{tabular}{|c|c|c|c|c|c|c|c|c|c|c|c|c|c|c|c|c|c|c|c|c|c|}
\hline \multirow[b]{2}{*}{ Colony } & \multicolumn{21}{|c|}{ Year (1995-2016) } \\
\hline & 95 & 96 & 97 & 98 & 99 & 00 & 01 & 02 & 04 & 05 & 06 & 07 & 08 & 09 & 10 & 11 & 12 & 13 & 14 & 15 & 16 \\
\hline Kharlov & 1 & 1 & 19 & 18 & 16 & 22 & 22 & 48 & 30 & 145 & 161 & 232 & 229 & 335 & 317 & 206 & & & & 203 & 241 \\
\hline Bjørnøya & & & & & & & & & & & & & & & & 2 & 2 & 10 & 11 & 25 & 52 \\
\hline
\end{tabular}

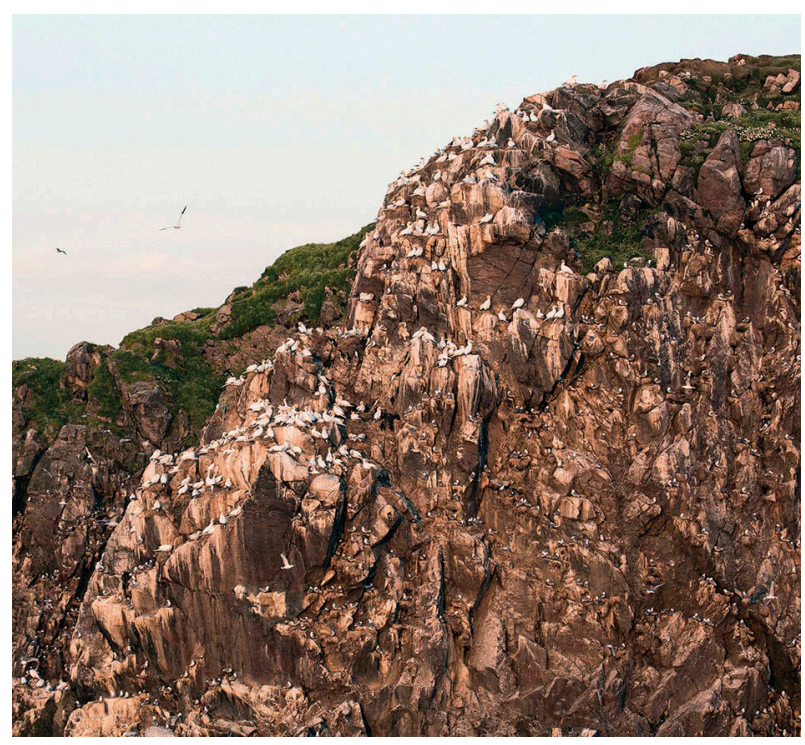

Figure 5. Northern gannet nests on the north coast of Kharlov, Russia, July 2016.

water into the Barents Sea reducing the area covered by cold, Arctic water (Spielhagen et al. 2011). This inflow was accompanied by the spread of boreal fish species such as haddock (Melanogrammus aeglefinus), herring (Clupea harengus) and mackerel (Scomber scombrus) into the Barents Sea and in the fjords of
Spitsbergen (Dalpadado et al. 2012; Berge et al. 2015). Herring and mackerel are very common food items of the gannet in the core of its distribution and recently also in northern Norway (Nelson 2002; Barrett 2016) such that their northward expansion made way for the opportunistic spread of the gannet to Bjørnøya. This mirrors the recolonization by gannets of Funk Island, off Newfoundland, in the 1930s and the establishment of new gannet colonies in eastern Iceland in the 1940s when mackerel appeared off the coasts during periods of warm water (Gudmundsson 1953; Montevecchi \& Myers 1997; Astthorsson et al. 2012; Freydis Vigfúsdottir, pers. comm.). Such a northward shift in distribution of boreal predators into the Barents Sea in the wake of preferred food species was anticipated (Dalpadado et al. 2012; Berge et al. 2015) and is welcome news in the light of the otherwise negative effects a warming climate has been having on the Svalbard wildlife, including seabirds (Descamps et al. 2017). How well gannets, which have one of the longest breeding periods among seabirds-nearly 4.5 months from egg-laying to fledging (Nelson 2002)-breeding in the North Atlantic, will fare so far north where the length of the breeding season is restrained by the shortness of the Arctic summers remains to be seen.

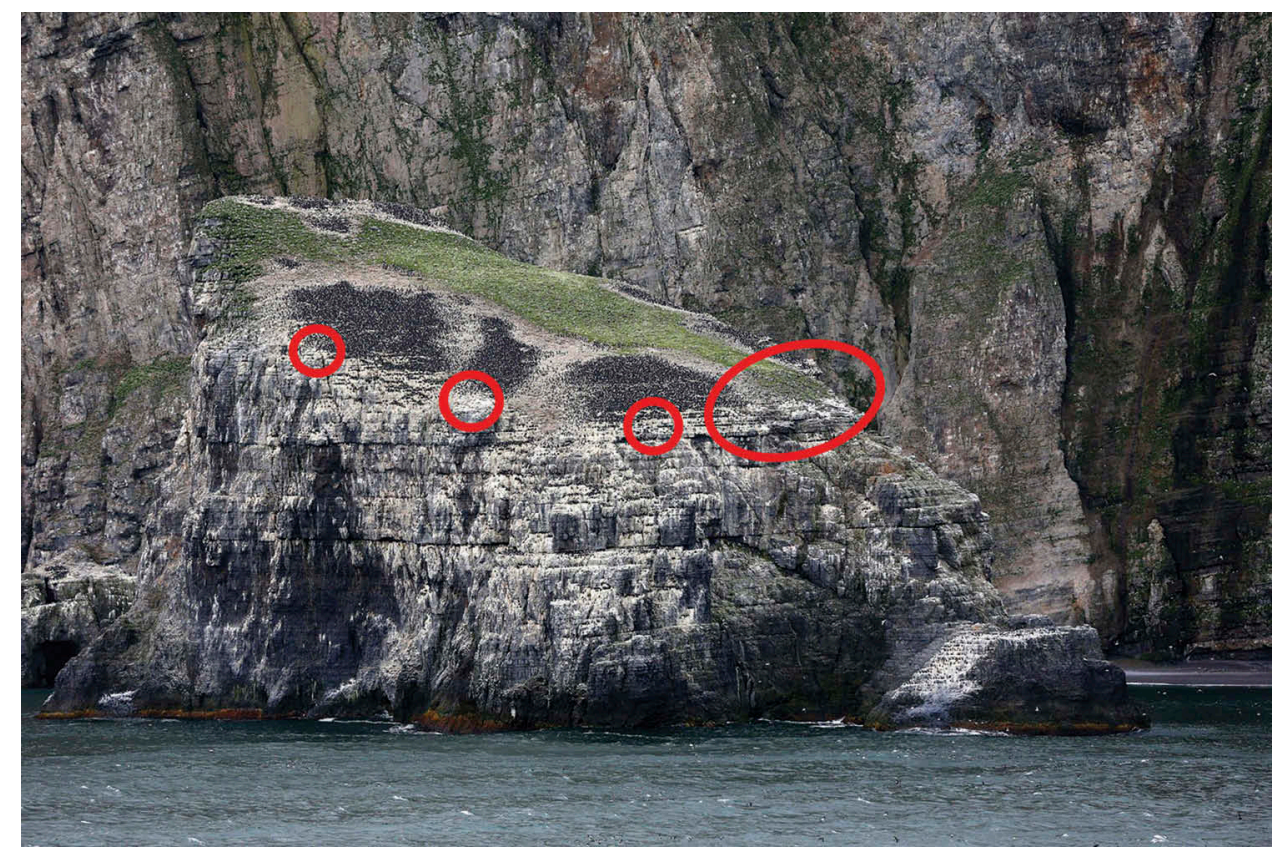

Figure 6. Northern gannet nests (encircled) along the top of the cliff at Alkeholmen, Bjørnøya, 23 June 2015. 
The extension of the gannet distribution eastwards to Kharlov in the 1990s was also during a period of warming in the southern Barents Sea that started in ca. 1980 and favoured the spread of fish such as herring along the Murman coast. This culminated in 2006 when the influx of warm Atlantic water reached a maximum (Krasnov \& Barrett 1997; Matishov et al. 2012; Ingvaldsen 2016) after a period when herring was the commonest food item found in the colony at Kharlov (Melnikov 2006). Sightings at Kharlov of eight birds that had been ringed in northern Norwegian colonies, five (four ringed as chicks and one as an adult) from Hovsflesa (a colony in Lofoten that was found suddenly abandoned in 2001 [Barrett 2008]) and three ringed as chicks at Storstappen suggest that some of the increase was due to Norwegian birds taking advantage of this opportunity.

A total of 3300 gannet AON in mainland northern Norway in 2015-16 was an increase of 600 (overall $22 \%$ ) or $3 \% \mathrm{y}^{-1}$ since 2008 , an annual increase that equates to the global gannet population rate of change. It was driven mainly by the reverse of the decline in Nordland and Troms that had been evident during the previous decade (Fig. 2; Barrett 2008). In Finnmark, however, numbers increased by only $9 \%$ as a result of a small decline at Syltefjord and a slightly larger increase at Storstappen. Furthermore, in Troms, numbers dropped steeply in the one colony at Kvitvær, but this was more than offset by a more than doubling $(+124 \%)$ of numbers in Nordland. That, in turn, was driven mainly by a large increase at Buholmene (from $126 \mathrm{AON}$ in 2008 to $725 \mathrm{AON}$ in 2015) and the establishment and increase at Store Forøya (Table 1). The reversal of the negative trend in the Lofoten/ Vesterålen region, in Nordland county, was nevertheless unexpected as it followed the abandonment of the two largest colonies in the region and a large (70\%) decline in numbers in 1995-2008. This decline was attributed partly to harassment from an increasing population of white-tailed eagles (Haliaeetus albicilla) (Barrett 2008; Pettex et al. 2015). Because the general recovery of sea eagle populations has recently been implicated in local declines of surface-nesting seabirds throughout the Northern Hemisphere (Hipfner et al. 2012), the increase in numbers in Norway that continued through the next decade (State of the Environment Norway 2017) was expected to cause a further decline in gannet numbers. Although recent reports from local tourist guides, birdwatchers and fishermen of eagles preying on near-fledging chicks on the nest at, e.g., Store Ulvøyholmen and Storstappen are a cause of concern (Pettex et al. 2015), it seems that gannets may have partly overcome this threat and are able to continue their increase in the region. White-tailed eagles have also been reported at Kharlov since 2000, becoming common since 2011. In 2015 and 2016, 10-15 birds were often seen causing widespread disturbance and population declines among the kittiwakes and guillemots but are not yet considered a serious threat to the gannets. So far, white-tailed eagles are only rare visitors at Bjørnøya. Changes in gannet population trends are often attributed to current food availability (e.g., Crawford et al. 2007), but there was no evidence that this was a factor during the decline in Lofoten/Vesterålen. Here gannets fed on high-energy fish such as herring, mackerel and saithe (Pollachius virens) during both the population decline and subsequent increase (Pettex et al. 2015; Barrett 2016).

The colony on Syltefjordstauren was the first to be established in northern Norway in 1961 and, like many of the other new colonies, increased rapidly in size during the first two decades $\left(35 \%\right.$ and $18 \% \mathrm{y}^{-1}$ respectively [Barrett \& Folkestad 1996]). The first nests were built on top of an isolated ca. $40 \mathrm{~m}$ high stack (Fig. 7) at the south end of a $3 \mathrm{~km}$ long

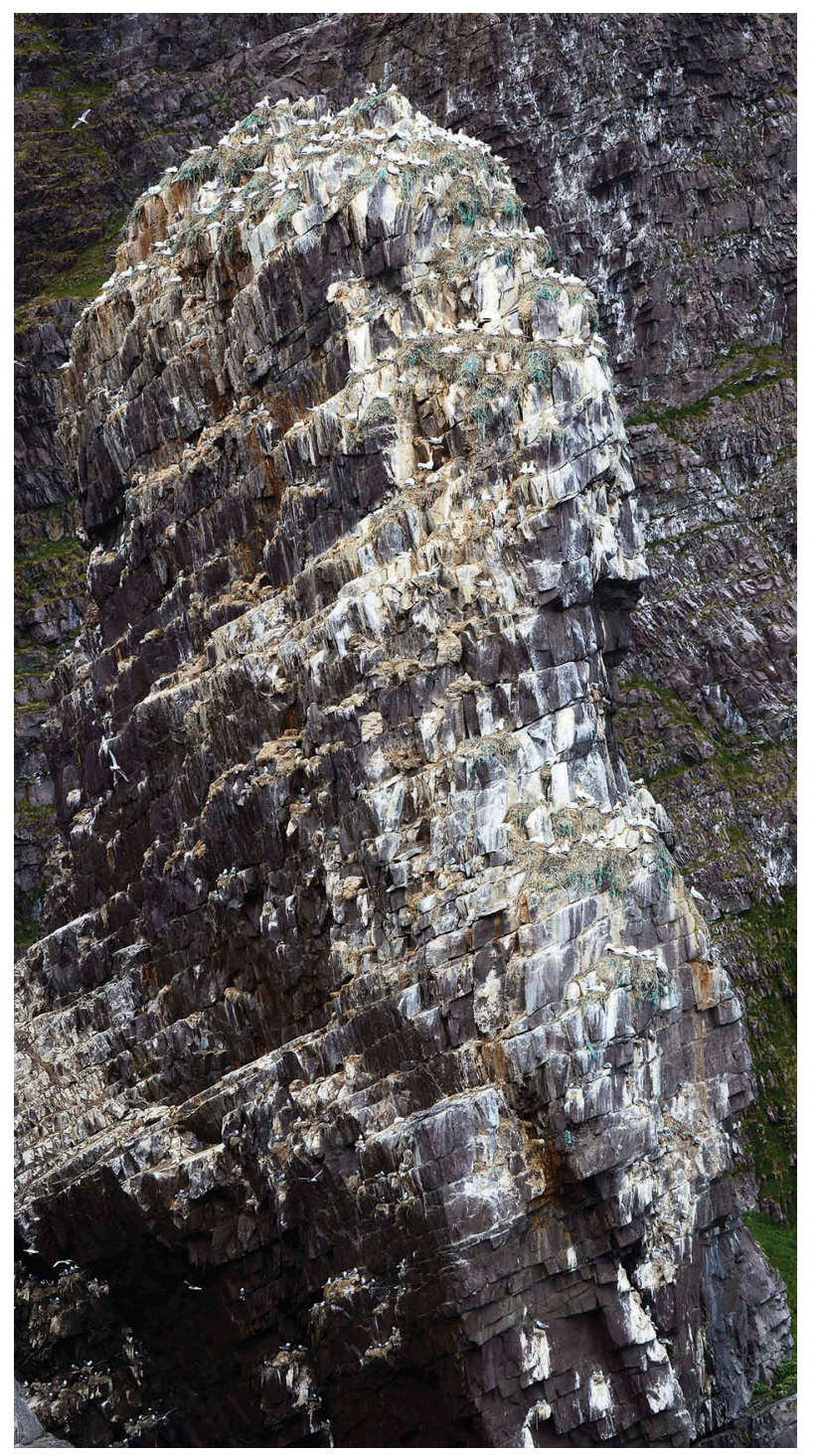

Figure 7. Northern gannet nests on the east face of Syltefjordstauren, with a small part of the main (abandoned) bird cliff in the background, 16 June 2016. 


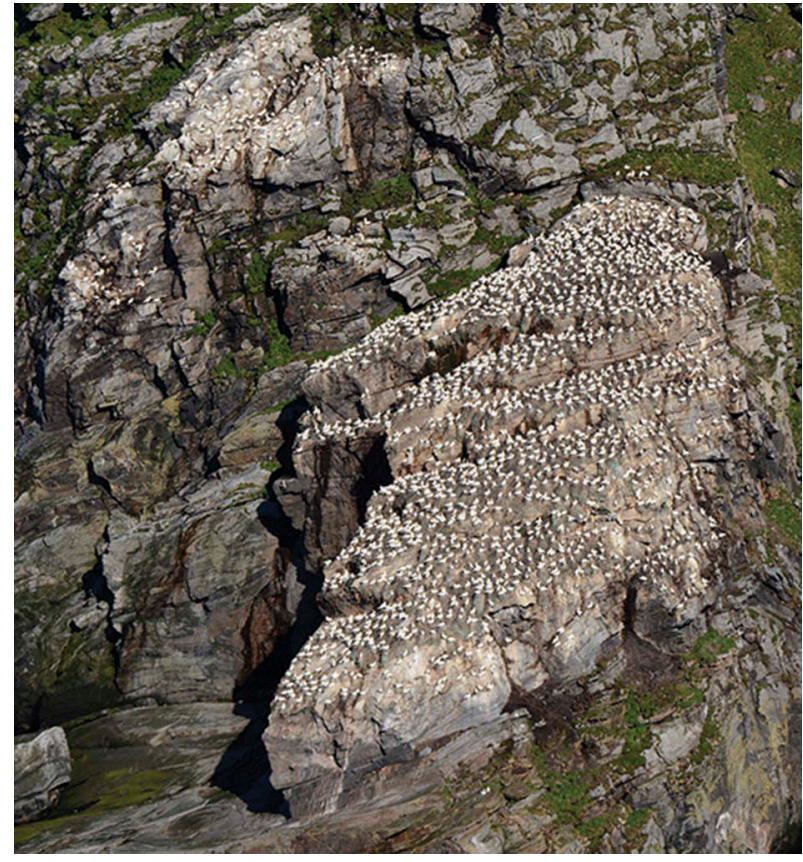

Figure 8. Northern gannet colony on Storstappen, Gjesvær, 27 May 2015, showing the fully occupied main site and prospecting birds on the slope above, left.

multispecies seabird colony (with then up to 140000 pairs of black-legged kittiwakes and ca. 10000 pairs of common guillemot [Norderhaug et al. 1977]). Since 1992, however, most of the sites suitable for gannets on the stack have been occupied, and numbers have hovered between 500 and 600 AON. It seems that the gannets have been strangely reluctant to build nests elsewhere on the main cliff, thus inhibiting an increase in numbers. This reluctance is more understandable today after kittiwake numbers have crashed and abandoned huge areas of the cliff (Barrett, pers. obs.), and numbers of sea eagles patrolling the main cliff have been reported by locals to have increased noticeably. Similarly, the main site at Storstappen seems to have become fully occupied, and a few tens of birds have spent many years prospecting a little higher up the cliff but with the completion of few nests (Fig. 8). As a result, the total numbers for Finnmark remained around 2000 AON between 2013 and 2015-16 (Fig. 2).

Although gannets seem to thrive in Norway, the population is still very small on a global scale. Including the ca. 3600 pairs at Runde (data downloaded from the SEAPOP website at http://www.sea pop.no/en/), the total Norwegian population in 2015-16 was ca. 6900 AON (up from ca. 3700 AON in 1995 [Barrett \& Folkestad 1997] and 4500 AON in 2008 [Pettex et al. 2015]). This, plus the approximately $250 \mathrm{AON}$ in Russia, constitutes only $2 \%$ of the ca. 340000 apparently occupied sites in 21 colonies in the British Isles (including 11000 at Bempton Cliffs, north-east England, in 2012 [Newton et al.
2015; Murray, Harris et al. 2015; Murray, Morgan et al. 2015; JNCC 2016) or 19\% of the Iceland population (37 000 apparently occupied sites in 2013-14 [Gardarsson in press]). This does not detract, however, from the plasticity of the population with recent and frequent abandonments and establishments of small colonies in northern Norway that is unique compared to other parts of the species' breeding range (Nelson 2002; Barrett 2008; this study). This is further manifested in the novelty of the (far) northand eastward spread of the species into the Barents Sea and the challenges gannets face from the Arctic amplification of global warming and the rapid climate changes forecast for the region (Spielhagen et al. 2011; Stocker et al. 2013).

\section{Acknowledgements}

Frederik Broms, Enok Olsen and John Stenersen are thanked for their observations of gannets in Nordland, Mia Husdal at the County Governor of Nordland for information concerning Kvitvær in 2009, Freydis Vigfúsdottir for information concerning early colonization in Iceland and Arnthor Gardarsson for a copy of his manuscript on gannets in Iceland. Roman Plotnikov is thanked for his field assistance and supplementary information concerning the colony at Kharlov. The aerial surveys were piloted by Fred Eilers and financed by the National Monitoring Programme for Seabirds (organized by Svein Håkon Lorentsen, Norwegian Institute for Nature Research, Trondheim). The analysis was supported by the SEAPOP and Tromsø University Museum. Work on Bjørnøya was financed by SEAPOP and the Norwegian Polar Institute and at Kharlov by the Kandalaksha State Nature Reserve. Very useful suggestions for improvement of the text were received from three reviewers of the submitted manuscript.

\section{Disclosure statement}

No potential conflict of interest was reported by the authors.

\section{Funding}

This work was supported by the National Monitoring Programme for Seabirds; Tromsø University Museum; SEAPOP; Norwegian Polar Institute; Kandalaksha State Nature Reserve.

\section{ORCID}

Mikhail Melnikov (D) http://orcid.org/0000-0003-0190-4733

\section{References}

Astthorsson O.S., Valdimarsson H., Gudmundsdottir A. \& Oskarsson G.J. 2012. Climate-related variations in the occurrence and distribution of mackerel (Scomber scombrus) in Icelandic waters. ICES Journal of Marine Science 69, 1289-1297. 
Barrett R.T. 2008. Recent establishments and extinctions of northern gannet Morus bassanus colonies in north Norway, 1995-2008. Ornis Norvegica 31, 172-182.

Barrett R.T. 2016. Diet of northern gannet Morus bassanus chicks in north Norway. Ornis Norvegica 39, 45-52.

Barrett R.T. \& Folkestad A.O. 1996. The status of the North Atlantic gannet Morus bassanus after 50 years in Norway. Seabird 18, 30-37.

Berge J., Heggland K., Lønne O.J., Cottier F., Hop H., Gabrielsen G.W., Nøttestad L. \& Misund O.A. 2015. First records of Atlantic mackerel (Scomber scombrus) from the Svalbard Archipelago, Norway, with possible explanations for the extension of its distribution. Arctic 68, 54-61.

Brun E. 1967. Hekking av havsule, Sula bassana, i Nord Norge. (Breeding of the gannet, Sula bassana, in Norway.) Sterna 7, 1-11.

Brun E. 1970. Havsulen, Sula bassana, etablert som hekkefugl I Lofoten. (The gannet, Sula bassana, established as a breeding bird in Lofoten.) Sterna 9, 141-147.

Crawford R.J.M., Dundee B.L., Dyer B.M., Kalges N.T.W., Meÿer M.A. \& Upfold L. 2007. Trends in numbers of Cape gannets (Morus capensis), 1965/1957 - 2005/2006, with a consideration of the influence of food and other factors. ICES Journal of Marine Science 64, 169-177.

Dalpadado P., Ingvaldsen R.B., Stige L.C., Bogstad B., Knutsen T., Ottersen G. \& Ellertsen B. 2012. Climate effects on Barents Sea ecosystem dynamics. ICES Journal of Marine Science 69, 1303-1316.

Descamps S., Aars J., Fuglei E., Kovacs K.M., Lydersen C., Pavlova O., Pedersen Å.Ø., Ravolainen V. \& Strøm H. 2017. Climate change impacts on wildlife in a High Arctic archipelago - Svalbard, Norway. Global Change Biology 23, 490-502.

Gardarsson A. in press. Icelandic colonies of the northern gannet in 2013-2014. Bliki.

Giagnoni R., Conti C.A., Canepa P. \& Nardelli R. 2015. First breeding records of northern gannet Morus bassanus in Italy. Avocetta 39, 93-95.

Gudmundsson F. 1953. Icelandic birds VII. The gannet (Sula bassana [L.]). Náttúrufræedingnum 23, 170-177.

Hipfner J.M., Blight L.K., Lowe R.W., Wilhelm S.I., Robertson G.J., Barrett R.T., Anker-Nilssen T. \& Good T.P. 2012. Unintended consequences: how the recovery of sea eagle Haliaeetus spp. populations in the Northern Hemisphere is affecting seabirds. Marine Ornithology 40, 39-52.

Ingvaldsen I. 2016. Barentshavet. (The Barents Sea). In I.E. Bakketeig et al. (eds.): Havforskningsrapporten 2016. (Institute of Marine Research Report 2016.) Fisken og Havet, Special Issue 1-2016. Pp. 88-89. Bergen: Institute of Marine Research.

JNCC (Joint Nature Conservation Committee) 2016. Seabird population trends and causes of change: 1986-2015. Accessed on the internet at http://jncc. defra.gov.uk/page-3201 on 26 September 2017.

Krasnov Y.V. \& Barrett R.T. 1997. The first record of North Atlantic gannets Morus bassanus breeding in Russia. Seabird $19,54-57$.
Matishov G., Moiseev D., Lyubina O., Zhichkin A., Dzhenyuk S., Karamushko O. \& Frolova E. 2012. Climate and cyclic hydrobiological changes of the Barents Sea from the twentieth to twenty-first centuries. Polar Biology 35, 1773-1790.

Melnikov M.V. 2006. Sostojanie gnezdovoj populjacii severnoj oluši na Vostočnom Murmane. (Status of the population of northern gannets in east Murman.) In E.N. Kuročkin (ed.): Ornitologičeskie issledovanija v Severnoj Evrazii. Tezisy. XII Meždunarodnoj ornitologičeskoj konferencii Severnoj Evrazii. (Ornithological studies in northern Eurasia. Abstracts of the XII International Ornithological Conference of Northern Eurasia.) Pp. 351352. Stavropol: Stavropol University Press.

Montevecchi W.A., Barrett R.T., Rikardsen F. \& Strann K.B. 1987. The gannet population in Norway, 1985. Fauna Norvegica, Serie C, Cinclus 10, 65-72.

Montevecchi W.A. \& Myers R.A. 1997. Centurial and decadal oceanographic influences on changes in northern gannet populations and diets in the north-west Atlantic: implications for climate change. ICES Journal of Marine Science 54, 608-614.

Murray S., Harris M.P. \& Wanless S. 2015. The status of the gannet in Scotland in 2013-2014. Scottish Birds $35,3-18$.

Murray S., Morgan G. \& Harris M.P. 2015. A count of northern gannets on Grassholm in 2015. British Birds 108, 691-692.

Nelson J.B. 2002. The Atlantic gannet. Great Yarmouth: Fenix Books Ltd.

Newton S.F., Harris M.P. \& Murray S. 2015. Census of gannet Morus bassanus colonies in Ireland in 2013-2014. Irish Birds 10, 215-220.

Norderhaug M., Brun E. \& Møllen G.U. 1977. Barentshavets sjøfuglressurser. (Barents Sea seabirds.) Norsk Polarinstitutt Meddelelser 104. Oslo: Norwegian Polar Institute.

Pettex E., Barrett R.T., Lorentsen S.-H., Bonadonna F., Pichegru L., Pons J.-B. \& Grémillet D. 2015. Contrasting population trends at seabirds colonies: is food limitation a factor in Norway? Journal of Ornithology 156, 397-406.

Spielhagen R.F., Werner K., Sørensen S.A., Zamelczyk K., Kandiano E., Budeus G., Husum K., Marchitto T.M. \& Hald M. 2011. Enhanced modern heat transfer to the Arctic by warm Atlantic water. Science 331, 450-453.

State of the Environment Norway 2017. Havørn. (White-tailed eagle.) Accessed on the internet at http://www.miljostatus.no/Havorn/on 26 September 2017.

Stocker T.F., Qin D., Plattner G.-K., Tignor M., Allen S. K., Boschung J., Nauels A., Xia Y., Bex V. \& Midgley P.M. (eds.) 2013. Climate change 2013. The physical science basis. Contribution of Working Group I to the fifth assessment report of the Intergovernmental Panel on Climate Change. Cambridge: Cambridge University Press. 